MaPan : Jurnal Matematika dan Pembelajaran

p-ISSN: 2354-6883 ; e-ISSN: 2581-172X

Volume 9, No 1, June 2021 (153-166)

DOI: https://doi.org/10.24252/mapan.2021v9n1a10

\title{
STUDENTS' REFLECTIVE THINKING IN MATHEMATICAL PROBLEM SOLVING
}

\author{
Rijalush Sholikhin1), Dian Septi Nur Afifah'2), Maryono ${ }^{3)}$ \\ ${ }^{1}$ Mathematics Department, Universitas Bhinneka PGRI \\ ${ }^{2}$ Mathematics Department, Universitas Bhinneka PGRI \\ ${ }^{3}$ Mathematics Department, UIN Sayyid Ali Rahmatullah Tulungagung \\ 1,2Jl. Mayor Sujadi Timur No. 7 Tulungagung \\ 3Jl. Mayor Sujadi Timur No. 46 Tulungagung \\ Email: rijalushsholikhin@gmail.com¹),dian.septi@ubhi.ac.id2), \\ mario_stain@yahoo.com $\left.{ }^{3}\right)$
}

Received June 08, 2021; Revised June 15, 2021; Accepted June 27, 2021

\begin{abstract}
:
This study aims to describe reflective thinking in solving mathematical problems on linear equations system with three variables based on mathematical abilities. This study uses a qualitative approach with case study type. The instruments in this study used tests and interviews. The subjects of this study came from 38 students grade X Natural Science 2 Islamic Senior High School 3 Blitar, taken one from each category of students with high, moderate, and low mathematical ability to be the subject of research. The data analysis techniques used are data reduction, data display, and conclusions drawing/verification. The validity test of data used persistent observation and triangulation. The research results obtained by students with high and moderate abilities can meet the phase of reacting, comparing, and contemplating in reflective thinking. Meanwhile, low mathematical ability students are only able to meet the reacting and comparing phases.
\end{abstract}

Keywords: Reflective Thinking, Mathematical Problems, Mathematical Ability

\section{BERPIKIR REFLEKTIF SISWA DALAM MENYELESAIKAN MASALAH MATEMATIKA}

\begin{abstract}
Abstrak:
Penelitian ini bertujuan untuk mendeskripsikan berpikir reflektif dalam menyelesaikan masalah matematika pada materi sistem persamaan linear tiga variabel berdasarkan kemampuan matematika. Penelitian ini menggunakan pendekatan kualitatif dengan jenis penelitian studi kasus. Instrumen dalam penelitian ini menggunakan tes dan wawancara. Subjek dari penelitian ini berasal dari 38 siswa kelas X MIA 2 MAN 3 Blitar, masing-masing satu dari tiap kategori siswa yang berkemampuan matematika tinggi, sedang, dan rendah. Teknik analisis data yang digunakan adalah reduksi data, penyajian data, dan penarikan kesimpulan/verifikasi. Uji keabsahan data menggunakan ketekunan pengamatan dan triangulasi. Hasil penelitian yang diperoleh adalah siswa berkemampuan tinggi dan sedang mampu memenuhi fase reacting,
\end{abstract}

Copyright (C) 2021, MaPan : Jurnal Matematika dan Pembelajaran 
comparing, dan contemplating dalam berpikir reflektif. Sementara itu, siswa dengan kemampuan rendah hanya mampu memenuhi fase reacting dan comparing.

Kata Kunci: Berpikir Reflektif, Masalah Matematika, Kemampuan Matematika

How to Cite: Sholikhin, R., Afifah, D. S. N., \& Maryono. (2021). Students' Reflective Thinking in Mathematical Problem Solving. MaPan : Jurnal $\begin{array}{lll}\text { Matematika dan Pembelajaran, 153-166. } & \text { 9(1), }\end{array}$ https://doi.org/10.24252/mapan.2021v9n1a10.

\section{INTRODUCTION}

athematics is a lesson taught at every level of the education unit.
Learning mathematics aims to equip students to develop Higher
Order Thinking Skills (HOTS) (Kamarullah, 2017). HOTS is the ability to connect, manipulate, and change knowledge and experience that has been owned critically and creatively to determine decisions in solving problems in new situations (Dinni, 2018). Parts of HOTS are critical thinking, creative thinking, logical thinking, analytic thinking, and reflective thinking (Kusumaningrum \& Saefudin, 2012). So, reflective thinking skills are part of higher-order thinking skills.

Dewey in Agustan, Juniati, \& Siswono (2017) has defined reflective thinking as active, persistent, carefully considering a belief or knowledge in which there are strong supporting reasons and the intended conclusion. According to Sabandar (2003), reflective thinking skills in mathematics, which include critical thinking and creative thinking skills like other thinking skills, will have the opportunity to be raised and developed when students are in an intense problem solving process. While according to Fuady (2017), reflective thinking is a process of connecting knowledge that has been possessed and is being studied in analyzing problems, evaluating, concluding, and deciding the best solution to a given problem. Mathematical reflective thinking ability can be interpreted as thinking critically to empower the knowledge they already have (Nindiasari \& Subhan, 2016). In other words, reflective thinking is the development of other higher-order ways of thinking that arise when students are faced with solving a new problem.

Hamilton, Boody, and Schon (in Anwar \& Sofiyan, 2018) mention that there are four characteristics of reflective thinking, namely: (a) reflection as retrospective analysis or recall, (b) reflection as a problem solving process, (c) 
self-critical reflection, and (d) reflection on belief and success. Meanwhile, according to Surbeck, Han, and Moyer, reflective thinking has three phases: reacting, comparing, and contemplating (Noer, 2008). First, reacting means reacting with personal attention to events/situations/problems. Second, comparing reactions with other experiences, such as referring to a general principle, is a theory. Third, contemplating, namely prioritizing a profound, constructive personal understanding of problems or difficulties. Table 1 shows indicators of reflective thinking in solving problems adapted from Ariestyan, Sunardi, and Kurniati (2016).

Table 1. Indicators of Reflective Thinking

\begin{tabular}{|c|c|c|}
\hline No. & Phase & Indicator \\
\hline 1. & Reacting & $\begin{array}{l}\text { a. Mention what is known in the problem. } \\
\text { b. State what is being asked in the problem. } \\
\text { c. State the relationship between what is known and } \\
\text { what is asked } \\
\text { d. Can explain that what is known is sufficient to } \\
\text { answer the problem being asked } \\
\text { e. State the method that will be used to solve the } \\
\text { problem. }\end{array}$ \\
\hline 2. & Comparing & $\begin{array}{l}\text { a. Explain the answers obtained from the results of } \\
\text { the work. } \\
\text { b. Connect the problem in question with problems } \\
\text { that have been encountered. } \\
\text { c. Relate the problem asked to the problems that } \\
\text { have been faced }\end{array}$ \\
\hline 3. & Contemplating & $\begin{array}{l}\text { a. Determine the purpose of the problem. } \\
\text { b. Detect the truth in determining the answer } \\
\text { c. Detect errors if they occur in determining the } \\
\text { answer. } \\
\text { d. Able to correct and explain answers if something } \\
\text { goes wrong. } \\
\text { e. Make conclusions correctly. }\end{array}$ \\
\hline
\end{tabular}

Reflective thinking skills can be developed through solving mathematical problems exercises. According to Sumarmo, problem solving is a process to overcome the difficulties encountered to achieve a goal. Meanwhile, according to Montague, mathematical problem solving is a complex cognitive activity accompanied by several processes and strategies (Harahap \& Surya, 2017). Mathematical problem solving is important because it is not only for the 
general purpose of teaching mathematics but is also the primary tool for doing or working in mathematics (Angkotasan, 2013). So, mathematical problem solving is an activity that involves cognitive through a series of process activities and strategies to achieve certain goals.

Based on the observations, many students have not applied reflective thinking in solving mathematical problems on the material for linear equations system with three variables. As a result, many students do not understand the concept and solve everyday or contextual problems from a system of linear equations with three variables, so that many errors occur in solving threevariable linear equation system problems. Cardo, Napisah, Wungo, Utama, \& Ambarawati (2020) state that in studying linear equations system with three variables, students find it difficult to understand the concept, solve contextual problems, find it difficult to apply a careful and thorough attitude, and find it difficult to write (conclude) the final answer. Widyawati, Afifah, \& Resbiantoro (2018) revealed that solving problems in the material becomes more difficult for students if associated with more complex questions. Therefore, it is very important to solve mathematical problems using mathematical thinking skills.

In this case, the reflective thinking skill is very important. This is because reflective thinking is the skill to think that connects the knowledge obtained at this time with the knowledge obtained in the past to help solve mathematical problems and everyday problems. The novelty in this study is to discuss students' reflective thinking skills in solving mathematical problems in the material of system of linear equations with three variables in which the concept of this material has been obtained in junior high school on the material of a system of linear equations with two variables. By reviewing based on mathematical ability, the extent to which students' reflective thinking skills solve these problems can be seen. So, according to this research, it is important to study reflective thinking skills because it is beneficial for developing students thinking skills in solving mathematical problems.

\section{METHODS}

This study is a qualitative approach, and the type of research uses case studies because this study discusses students' reflective thinking skills in solving mathematical problems. More details about the process in this research can be seen in figure 1. 


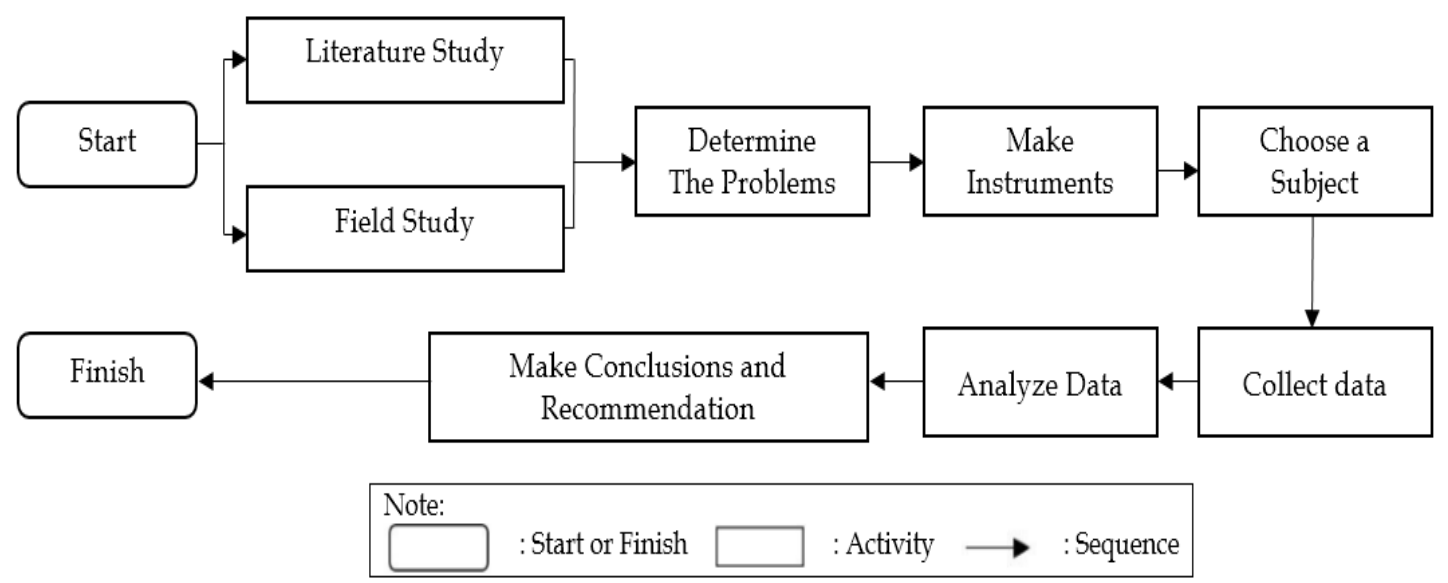

Figure 1. Research Process

The instruments used include tests on the linear equation system with three variables and interviews. The function of the test is to find out the students' reflective thinking in solving problems of linear equation system with three variables. At the same time, the interview aims to explore more in-depth information related to reflective thinking in solving the problems of the linear equation system with three variables. The subjects of this study came from 38 students of grade X Natural Science 2 Islamic Senior High School 3 Blitar, then 3 students were taken with categories 1 student with high mathematical ability, 1 student with moderate mathematical ability, and 1 student with low mathematical ability. Taking students as research subjects are based on their mathematical abilities from the results of the test. Categorizing mathematical abilities using high, medium, and low can help the research process focus more on reflective thinking problems.

Using Miles and Huberman's data collection technique, there are three data analysis techniques in qualitative research. The first step in reducing data is to categorize students according to their level of mathematical ability based on the results of the answers that have been done. One from each category of the high, medium, and low mathematical ability is taken to be interviewed to explore information about their reflective thinking abilities. The second stage is to present the data, which displays the results and discussion of the research obtained from the data reduction stage. The third stage is conclusions drawing, namely concluding the results and related discussions in this study. Persistent observation and triangulation are used to check the validity of the data. 


\section{RESULTS AND DISCUSSION}

In this section, the results of problem solving tests and interviews with research subjects will be presented. IR is a research subject with high mathematical ability, NHM is a subject of moderate mathematical ability, and $\mathrm{AN}$ is a low mathematical ability subject.

\section{Reflective Thinking of Students with High Mathematical Ability}

In the reacting phase, IR is able to write down what is known, as shown in figure 2.

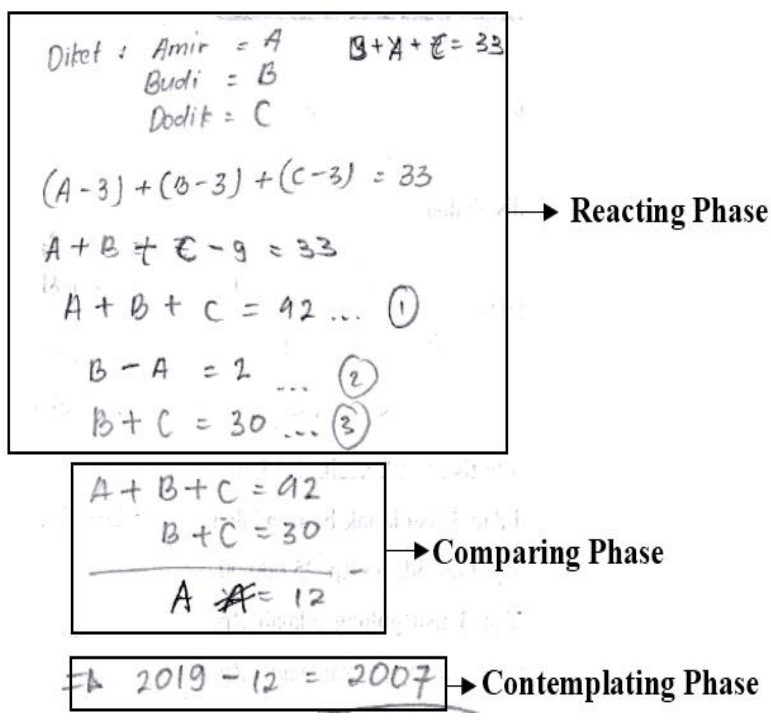

Figure 2. Answers of IR Subject

Based on figure 1, IR is able to write down what is known and the form of the equation clearly. This means that in reflective thinking in the reacting phase, the subject has fulfilled one indicator, namely being able to write down what is known, while there are five indicators in this phase. To find out other indicators of IR's reflective thinking in this phase, seen from an interview. Based on the interview, information was obtained that the subject is able to mention things that are known, things that are asked, the relationship between what is known and what is being asked by giving the reason being asked is already in the problem and can be solved by using what is known. Furthermore, IR stated that what was known was quite helpful in answering what was asked because what was known was very clear to answer the question, and IR can mention the right method in solving the problem, namely by using the elimination method.

Figure 1 in the comparing phase shows that the subject can determine the answer to the problem given correctly. The steps taken by the subject to solve the problem are very coherent and clear, namely starting from assuming then 
eliminating several equations to get one of the values of the variables asked in the problem. So that in this phase, the subject has been able to determine the answer correctly, while the indicator needed in this phase is able to explain the answers obtained. The interview results showed that the subject was able to explain how to get answers to the problem clearly. IR stated that he had faced the same problem as the problem, meaning that the subject had been able to relate the problem asked to the problem that the subject had faced in the results of this interview.

Figure 1 in the contemplating phase shows that the subject only wrote down the final result, $2019-12=2007$. without writing the conclusion sentence, while one of the indicators in the contemplating phase was making the right conclusion. The interview results show that the subject can determine the problem in what year Amir was born if the current year is 2019. The subject stated that he was correct in determining the answer, meaning that the subject had detected the truth in determining the answer in the results of this interview. In determining the error in determining the answer, the subject stated that there were no errors and the answers given were correct, so that the results of this interview showed that the subject could detect errors. The subject is able to state the right conclusion for the problem, namely Amir was born in 2007.

\section{Reflective Thinking of Students with Moderate Mathematical Ability}

For NHM subject, in the reacting phase, the subject is able to write down what is known, as shown in figure 3.

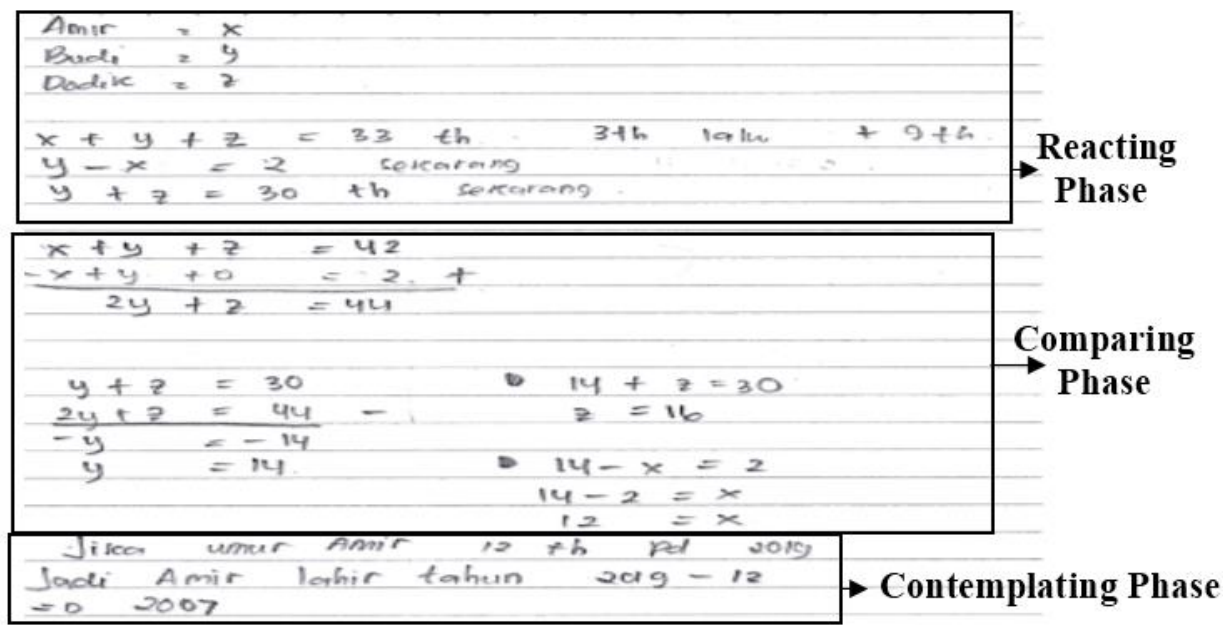

Figure 3. Answers of NHM Subject 
Based on figure 3, NHM wrote what he knew and its equations, but the subject had not finished writing the equation form in the first equation. In figure 3 , the subject did not write down the question asked. Therefore, the subject meets one indicator in the reacting phase, which is to mention what is known, while there are five indicators in this phase. Then, to find out other indicators in the reflective thinking of NHM in the reacting phase, it is supported by the interview results, which show that the subject is able to mention things that are known, things to ask, mention the relationship between what is known and what is being asked and explains the reason that what is known is like a keyword to answer what is known, states that what is known has been quite helpful in answering the question asked, and is able to mention the right method to solve the problem.

In the comparing phase, NHM is able to determine the answer to the given problem. If we look at the method of solving the problem of NHM, the process is longer than other subjects because NHM performs two eliminations and then looks for all the values for each variable. So, based on figure 3, NHM is able to determine the answer to the problem given, but the indicators needed in this phase are able to explain the answers obtained from the results of the settlement. Based on the interview results, the subject explained the solution to the problem given clearly. The subject stated that he had faced the same problem as the one given, meaning that in the results of this interview, the subject had connected the problem asked with the problem he had faced. Then the subject mentioned that there was a connection between what was asked and the problems he had faced and mentioned the relationship.

In the contemplating phase, NHM wrote the conclusion correctly. Based on the problem solving test results, the subject has met one indicator in the contemplating phase, namely being able to draw conclusions correctly, while in this phase, there are 5 indicators. From interview results, the subject can explain the intent of the problems given clearly. Then the subject stated that the answer he did was correct, meaning that in the results of this interview, the subject had detected the answer he had done was correct. The subject also stated that there was no error in determining the answer to the problem given. Furthermore, the subject is correct in making conclusions about the problem given.

\section{Reflective Thinking of Students with Low Mathematical Ability}

For AN subjects in the reacting phase, $\mathrm{AN}$ is able to write down what is known but not complete, as shown in figure 4 . 


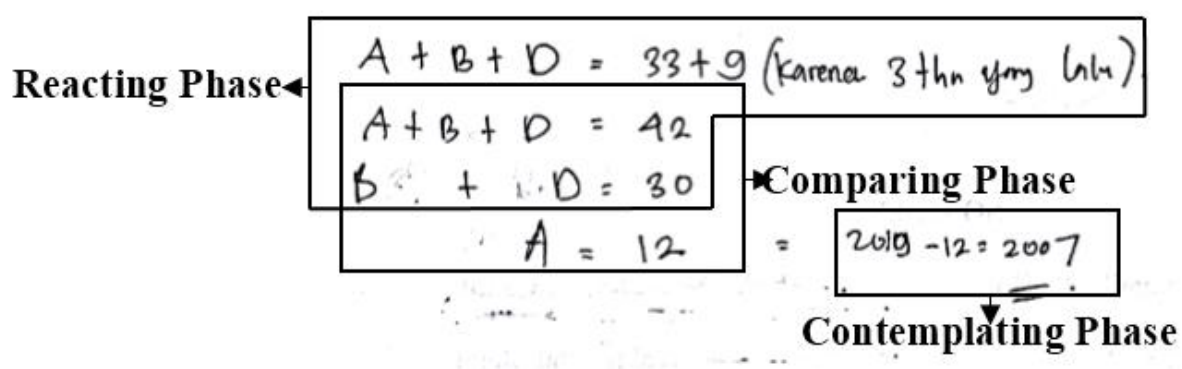

Figure 4. Answers of AN Subject

Figure 4 shows that $\mathrm{AN}$ wrote what is known in the form of the equations, but the subject has not written an equation representing Amir's age is 2 years less than Budi's age. In figure 4, the subject has not written down the question asked. So, based on the AN answer, it has not met all the indicators in this phase. There are five indicators in this phase. To find out the indicators that are the subject is able to fulfill, it is supported by the results of the interview, which show that the subject can mention things that are known, things that are asked, state and explain the relationship between what is known and what is being asked along with the reasons, namely having to complete what is known first. The subject states that what is known is not helpful enough to solve the problem asked because of having to know the formula. Then the subject has not been able to mention the right method to solve the given problem.

In the comparing phase, AN immediately wrote down the results so that the researcher could not capture information from what the subject was doing. So, based on figure 4 , $\mathrm{AN}$ has not met the indicators in this phase, and if it is based on the results of the problem solving test, AN did not know all the indicators in this phase. Based on the interview results, the subject had difficulty explaining this, but the researcher was able to capture what the subject meant by using the existing equations.

In the contemplating phase, $\mathrm{AN}$ only wrote the final answer without writing the conclusion sentence, while what is needed in this indicator is to draw conclusions correctly. So, based on figure 4, the subject has not met all the indicators in this phase, and the results of the problem solving test have not been able to explain the indicators that the subject is able to fulfill. Therefore, an interview is needed to explore this. Based on the interview results, the subject mentioned the problems he faced in the given problem, namely the problem with things that were known to be solved first. The subject also stated that the answer he did was correct. Then the subject also stated that there were no errors 
in determining the answer to the problem given. Furthermore, the subject concludes appropriately.

Based on the research results, several findings in the study that will become the focus of research are: 1) Subject with high mathematical abilities can meet all indicators in each phase of reflective thinking; 2) Subject with moderate mathematical ability have several indicators that have not been fulfilled in several phases of reflective thinking so that it will affect the reflective thinking process; 3) Subject with low mathematical ability have many indicators that have not been met in each phase of reflective thinking so that it will affect the reflective thinking process.

High mathematical ability subject is able to fulfill every phase of reflective thinking, and it can be proven that the subject is able to meet the indicators in each phase of reflective thinking so that the level of reflective thinking of subject with high mathematical abilities is at the reflective level because he is able to go through the reacting, comparing, and contemplating phases (Nisak, 2013). This is also reinforced by the opinion, which states that the higher the students' initial mathematical abilities, the higher the achievement and improvement of students' mathematical reflective thinking abilities (Nindiasari, Kusumah, Sumarmo, \& Sabandar, 2014).

One of the characteristics of reflective thinking is a reflection as a problem solving process, and this is very necessary because it analyzes and explains problems before taking action (Anwar \& Sofiyan, 2018). According to Rasiman (2012), for the subject with the high mathematical ability to understand the problem, the subject can identify the facts in a mathematical problem clearly and logically and formulate the main points of the problem carefully. Regarding making a plan of completion and revealing concepts/theorems, the subject does not experience obstacles, so he immediately finds the right rules. In implementing the plan, choosing the method or revealing the theorem can be done correctly and with logical considerations, and the calculation process can work correctly and relatively quickly. This shows that the thinking procedure is quite good. At the stage of re-examining, the subject has evaluated the steps in completing it carefully and thoroughly because the subject retries the steps one by one carefully so that the subject can distinguish between conclusions based on valid and invalid logic. This agrees with Afifah and Nafi'an (2019) that subjects with high mathematical ability are able to solve problems well.

Moderate mathematical ability subject is also able to fulfill every phase of reflective thinking. So that the level of reflective thinking of subject with 
moderate mathematical abilities is at the reflective level because the subject is able to go through the reacting, comparing, and contemplating phases (Nisak, 2013). The opinion reinforces this that moderately capable students can understand the problems given very well, plan problem solving very well, execute plans very well, and re-examine the answers obtained (Rahmawati \& Maryono, 2018). Subjects who have high and moderate mathematical abilities have a good understanding of the problem in mathematics. It can be seen when solving a problem, the subject is able to restate a known concept and classify it according to specific properties appropriately, is able to apply the concept algorithmically and present it in the form of the correct representation, and to obtain student answers, associate various predetermined concepts (Komariyah, Afifah, \& Resbiantoro, 2018).

Low mathematical ability subject is able to fulfill the reacting and comparing phases. The subject did not meet the contemplating phase because the subject was only able to fulfill one indicator, namely, being able to determine the purpose of the problems at hand. So, reflective thinking of a subject with low mathematical ability is at a moderately reflective level because the subject is only able to fulfill the reacting and comparing phases (Nisak, 2013). This is reinforced by the opinion of Rasiman (2013) that the subject has low ability to understand the problem at the stage of determining what is known, the subject can mention the known data, and at the stage of determining what is asked, the subject can mention the subject matter, but requires a stimulus from the researcher. In planning the completion, the subject has not fully disclosed at the stage of planning the completion steps. The steps are incomplete in carrying out the subject's plan, and the work is not detailed in sequence. In revealing the definition/formula, the subject still has difficulty because he does not immediately write down the rules that will be used. The subject also made mistakes in writing the rules. In the stage of evaluating or re-examining the results of the work, the subject has not carried out an evaluation that has been made carefully, and this is because the subject only rereads the steps one by one. Then the subject believes that the final answer is correct because he has read it repeatedly. Therefore, the subject has not been able to draw conclusions based on the right reasons. Agree with Salido and Dasari (2019) that low-ability subjects are able to understand questions before working, answer questions according to routine experience, have not been able to explain the completion steps, ignore difficult questions, and do not re-check answers. 


\section{CONCLUSION}

Based on the research and discussion results, it can be concluded that students' reflective thinking with high mathematical abilities in solving mathematical problems on a linear equation system with three variables can fulfill the reacting, comparing, and contemplating phases in reflective thinking. Student's reflective thinking with the moderate mathematical ability to solve mathematical problems on the material of a linear equation system with three variables can fulfill the reacting, comparing, and contemplating phases in reflective thinking. Student's reflective thinking with low ability to solve mathematical problems with a linear equation system with three variables can fulfill the reacting and comparing phases in reflective thinking.

Based on the research results, the researchers convey that it is hoped that this reflective thinking research in solving mathematics problems can be a provision or knowledge for students to improve learning mathematics, considering that every material in mathematics is sustainable and related. Furthermore, with this research, mathematics teachers are able to develop teaching materials and choose the right learning strategy in the classroom, considering students different mathematical abilities in understanding mathematical material.

\section{REFERENCES}

Afifah, D. S. N., \& Nafi'an, M. I. (2019). Analizing of field independent and dependent students' understanding in solving statistical problems based on ontosemiotic approach. Journal of Physics: Conference Series, 1321(2), 22100. https:/ / doi.org/10.1088/1742-6596/1321/2/022100.

Agustan, S., Juniati, D., \& Siswono, T. Y. E. (2017). Reflective thinking in solving an algebra problem: a case study of field independent-prospective teacher. Journal of Physics: Conference Series, 893(1), 1-6. https:/ / doi.org/ 10.1088/1742-6596/893/1/012002.

Angkotasan, N. (2013). Model PBL dan cooperative learning tipe TAI ditinjau dari aspek kemampuan berpikir reflektif dan pemecahan masalah matematis. Pythagoras: Jurnal Pendidikan Matematika, 8(1), 92-100. https: // doi.org/10.21831/pg.v8i1.8497.

Anwar, \& Sofiyan. (2018). Teoritik tentang berpikir reflektif siswa dalam pengajuan masalah matematis. Jurnal Numeracy, 5(1), 91-101. https:// doi.org/10.46244/NUMERACY.V5I1.330.

Ariestyan, Y., Sunardi, S., \& Kurniati, D. (2016). Proses berpikir reflektif siswa dalam menyelesaikan soal matematika materi sistem persamaan linear dua variabel. Kadikma, 7(1), 94-104. https://doi.org/10.19184/KDMA. V7I1.5472. 
Cardo A. P., D., Napisah, D., Wungo, D. D., Utama, G. D., \& Ambarawati, M. (2020). Analisis kesulitan siswa dalam mempelajari sistem persamaan linear tiga variabel. Laplace: Jurnal Pendidikan Matematika, 3(1), 27-42. https:// doi.org/10.31537/laplace.v3i1.311.

Dinni, H. N. (2018). HOTS (high order thinking skills) dan kaitannya dengan kemampuan literasi matematika. Prisma Prosiding Seminar Nasional Matematika, 1, 170-176. Retrieved from https://journal.unnes.ac.id/sju/ index.php/prisma/article/view/19597.

Fuady, A. (2017). Berfikir reflektif dalam pembelajaran matematika. JIPMat, 1(2), 104-112. https:// doi.org/10.26877/jipmat.v1i2.1236.

Harahap, E. R., \& Surya, E. (2017). Kemampuan pemecahan masalah matematis siswa kelas VII dalam menyelesaikan persamaan linear satu variabel. Edumatica: Jurnal Pendidikan Matematika, 07(01), 44-54. https://doi.org/ 10.22437/edumatica.v7i01.3874.

Kamarullah, K. (2017). Pendidikan matematika di sekolah kita. Al Khawarizmi: Jurnal Pendidikan Dan Pembelajaran Matematika, 1(1), 21-32. https:/ / doi. org/10.22373/jppm.v1i1.1729.

Komariyah, S., Afifah, D. S. N., \& Resbiantoro, G. (2018). Analisis pemahaman konsep dalam memecahkan masalah matematika ditinjau dari minat belajar siswa. SOSIOHUMANIORA: Jurnal Ilmiah Ilmu Sosial Dan Humaniora, 4(1), 1-8. https:/ / doi.org/10.30738/sosio.v4i1.1477.

Kusumaningrum, M. \& Saefudin, A. A. (2012). Mengoptimalkan kemampuan berpikir matematika melalui pemecahan masalah matematika. Prosiding Kontribusi Pendidikan Matematika dan Matematika Dalam Membangun Karakter Guru Dan Siswa, 571-580.

Nindiasari, H. \& Subhan, D. A. (2016). Desain didaktis tahapan kemampuan dan disposisi berpikir reflektif matematis berdasarkan gaya belajar. Jurnal Kependidikan: Penelitian Inovasi Pembelajaran, 46(2), 219-232. https://doi.org/10.21831/jk.v46i2.10681.

Nindiasari, H., Kusumah, Y. S., Sumarmo, U., \& Sabandar, J. (2014). Pendekatan metakognitif untuk meningkatkan kemampuan berpikir reflektif matematis siswa SMA. Edusentris, 1(1), 80-90. https://doi.org/10.17509 /edusentris.v1i1.136.

Nisak, L. (2013). Analisis kemampuan berpikir reflektif siswa dalam memecahkan masalah berbentuk semantik, figural, dan simbolik pada pokok bahasan fungsi kelas XI IPA di MAN Nglawak Kertosono Nganjuk. Undergraduated Thesis. UIN Sunan Ampel Surabaya.

Noer, S. H. (2008). Problem-based learning dan kemampuan berpikir reflektif dalam pembelajaran matematika. Semnas Matematika dan Pendidikan Matematika 2008, 267-280.

Rahmawati, N., \& Maryono, M. (2018). Pemecahan masalah matematika bentuk soal cerita berdasarkan model polya pada siswa kelas VIII MTs materi 
pokok SPLDV. Jurnal Tadris Matematika, 1(1), 23-34. https://doi.org/ 10.21274/jtm.2018.1.1.23-34.

Rasiman, R. (2012). Penelusuran proses berpikir kritis dalam menyelesaikan masalah matematika bagi siswa dengan kemampuan matematika tinggi. AKSIOMA: Jurnal Matematika Dan Pendidikan Matematika, 3(1), 1-12. https:// doi.org/10.26877/AKS.V3I1/MARET.221.

Rasiman, R. (2013). Proses Berpikir kritis siswa SMA dalam menyelesaikan masalah matematika bagi siswa dengan kemampuan matematika rendah. Prosiding Seminar Nasional Matematika Dan Pendidikan Matematika FMIPA UNY, 185-192.

Sabandar, J. (2003). Berpikir Reflektif dalam Pembelajaran Matematika.

Salido, A., \& Dasari, D. (2019). The analysis of students' reflective thinking ability viewed by students' mathematical ability at senior high school. Journal of Physics: Conference Series, 1157(2), 1-6. https://doi.org/10. 1088/1742-6596/1157/2/022121.

Widyawati, A., Afifah, D. S. N., \& Resbiantoro, G. (2018). Analisis kesalahan siswa dalam memecahkan masalah lingkaran berdasarkan taksonomi solo pada kelas VIII. Jurnal Pendidikan Matematika Dan Sains, 6(1), 1-9. Retrieved from https://journal.uny.ac.id/index.php/jpms/article/ view/15087. 